\title{
Matrix metalloproteinases 7, 8, 12, 13 gene haplotypes associated with colorectal cancer in a Mexican population
}

\author{
José M. Moreno-Ortiz, ${ }^{1}$ Melva Gutiérrez-Angulo, ${ }^{2}$ Ruth Ramírez-Ramírez, ${ }^{3}$ Anahí González-Mercado, ${ }^{1}$ \\ Alexis S. Suárez-Villanueva, ${ }^{3,4}$ Miriam Partida-Pérez, ${ }^{5}$ Víctor Maciel-Gutiérrez ${ }^{6}$ and \\ Ma. de la Luz Ayala-Madrigal ${ }^{1 *}$ \\ ${ }^{1}$ Department of Molecular Biology and Genomics, Instituto de Genética Humana Dr. Enrique Corona Rivera, University Center of Health Sciences, \\ Universidad de Guadalajara; ${ }^{2}$ Department of Health Sciences, Centro Universitario Los Altos, Universidad de Guadalajara; ${ }^{3}$ Department of Cellular \\ and Molecular Biology, University Center of Biological and Agricultural and Livestock Sciences, Universidad de Guadalajara; ${ }^{4}$ School of Medicine, \\ Universidad del Valle de México, Zapopan Campus, Zapopan; ${ }^{5}$ Department of Medical Sciences, Centro Universitario de la Costa, Universidad de \\ Guadalajara; ${ }^{6}$ Department of Colon and Rectum, Hospital Civil Dr. Juan I. Menchaca, Guadalajara. Jalisco, Mexico
}

\begin{abstract}
Background: Matrix metalloproteinases (MMPs) are involved in tumor invasion and progression in colorectal cancer (CRC). Variants rs11568818, rs11225395, rs2276109 and rs2252070 have been associated with this neoplasm. Objective: To evaluate MMPs 7, 8, 12, and 13 haplotypes and their association with CRC. Material and methods: One-hundred and four patients and 112 healthy individuals were genotyped by polymerase chain reaction-restriction fragment length polymorphism analysis (PCR-RFLP). For the association analysis, odds ratio and confidence interval values were calculated. Haplotype and linkage disequilibrium (LD) analysis was performed with Arlequin software, v3.5. Results: $L D$ was present between rs2276109 and rs2252070. Haplotypes rs11568818(A)-rs11225395(T)-rs2276109(A)-rs2252070(A) and rs11568818(A)-rs11225395(C)rs2276109(A)-rs2252070(G) were associated with CRC risk, and haplotypes rs11568818(G)-rs11225395(C)-rs2276109(A)rs2252070(A) and rs11568818(A)-rs11225395(T)-rs2276109(A)-rs2252070(G), with protection. Conclusion: Variants rs2276109 and rs2252070 showed genetic linkage. Two haplotypes were associated with the development of CRC (ATAA and ACAG) and two were associated with protection (GCAA and ATAG). This study represents the first report on variants rs 11225395 and rs2276109 frequency in a Mexican population.
\end{abstract}

KEY WORDS: Colorectal cancer. Haplotypes. Matrix metalloproteinases. Mexican population.

\section{Haplotipos en los genes de las metaloproteinasas 7, 8, 12 y 13 asociados con cáncer colorrectal en población mexicana}

\section{Resumen}

Antecedentes: Las metaloproteinasas (MMP) se involucran en invasión y progresión tumoral en cáncer colorrectal (CCR). Las variantes rs 11568818, rs11225395, rs2276109 y rs2252070 se han asociado con esta neoplasia. Objetivo: Evaluar haplotipos de las MMP 7, 8, 12, y 13 y su asociación con CCR. Material y métodos: Se genotipificaron 104 pacientes y 112 individuos sanos mediante reacción en cadena de la polimerasa con análisis del polimorfismo de los fragmentos de restricción (PCR-RFLP). Para el análisis de asociación fueron calculados valores de odds ratio e intervalo de confianza. El análisis de haplotipos y desequilibrio de ligamiento (LD) se realizó con el software Arlequin v3.5. Resultados: Se presentó $L D$ entre rs2276109 y rs2252070. Los haplotipos rs11568818(A)-rs11225395(T)-rs2276109(A)-rs2252070(A) y

Correspondence:

${ }^{*}$ Ma. de la Luz Ayala-Madrigal

E-mail: luz.ayala@academicos.udg.mx
Date of reception: 19-01-2021

Date of acceptance: $27-04-2021$

DOI: 10.24875/GMM.M21000609
Gac Med Mex. 2021;157:531-536

Contents available at PubMed

www.gacetamedicademexico.com

0016-3813/@ 2021 Academia Nacional de Medicina de México, A.C.. Published by Permanyer. This is an open access article under the CC BY-NC-ND license (http://creativecommons.org/licenses/by-nc-nd/4.0/). 
rs11568818(A)-rs11225395(C)-rs2276109(A)-rs2252070(G) se asociaron con riesgo de CCR y los haplotipos rs11568818(G)rs11225395(C)-rs2276109(A)-rs2252070(A) y rs11568818(A)-rs11225395(T)-rs2276109(A)-rs2252070(G) con protección. Conclusión: Las variantes rs2276109 y rs2252070 mostraron ligamiento génico. Dos haplotipos fueron asociados con el desarroIlo de CCR (ATAA y ACAG) y dos fueron asociados con protección (GCAA y ATAG). Este estudio representa el primer reporte de frecuencias de las variantes rs11225395 y rs2276109 en población mexicana.

PALABRAS CLAVE: Cáncer colorrectal. Haplotipos. Metaloproteinasas. Población mexicana.

\section{Introduction}

Colorectal cancer (CRC) is one of the most prevalent cancers in the world. Its incidence and mortality markedly vary between countries. ${ }^{1}$ In the Mexican population, CRC is the third most common cause of mortality. ${ }^{2}$ Carcinogenesis in CRC is a complex process where normal cells undergo different genetic and epigenetic alterations, which turn them into malignant cells. $^{3}$ In this process, matrix metalloproteinases (MMPs) participate in extracellular matrix proteins (ECM) remodeling and degradation, and are therefore involved in tumor progression and invasion by catalyzing cell proliferation, migration and differentiation. ${ }^{4,5}$ Metalloprotease genes are located very close, between chr11:102530930 -102955810 (GRCh38.p13). Variants in MMP genes promoter have been associated with CRC. ${ }^{6-8}$ MMP7 rs11568818 (-181A>G), MMP8 rs11225395 (-799C>T), MMP12 rs2276109 $(-82 A>G)$ and MMP13 rs2252070 (-77A>G) have been implicated in several types of cancer. Therefore, the purpose of the present study was to infer haplotypes between these variants and their possible association with CRC in Mexican patients.

\section{Material and Methods}

\section{Subjects}

This study included 104 patients with colorectal adenocarcinoma histopathological diagnosis who had not received treatment with radiotherapy or chemotherapy. The reference group consisted of 112 healthy peripheral blood donors. All samples were collected between December 2008 and December 2013, and informed consent from participants was obtained as well at Hospital Civil de Guadalajara "Dr. Juan I. Menchaca". Questionnaires were applied to assess patient lifestyle; in addition, medical records were reviewed to obtain clinical-pathological characteristics. The study meets the criteria of the Declaration of Helsinki, and the ethics and research committees of the University Center of Health Sciences of the University of Guadalajara and Hospital Civil "Dr. Juan I. Menchaca" of Guadalajara, Jalisco, Mexico, approved the study (registration numbers: $\mathrm{Cl}-14409$ and 935/09, respectively).

\section{Genotyping}

DNA was extracted using peripheral blood samples from both patients and individuals from the general population group, using a modification of the CTABDTAB method. ${ }^{9}$ Variants were genotyped by polymerase chain reaction-restriction fragment length polymorphism analysis (PCR-RFLP). Genotyping and digestion conditions for rs11568818 (MMP7) and rs2252070 (MMP13) have been described by our working group. ${ }^{10}$ The following primers were designed to identify the rs11225395 (MMP8) variant: 5'-AGCTGCTGCTCCACTATG-3' and 5'-TCTGGAGGATGTGGTTTG-3'. Previously reported primers ${ }^{11}$ were used to identify rs2276109 (MMP12). PCR reactions were performed in a $25 \mu \mathrm{L}$ volume containing $100 \mathrm{ng}$ of DNA. The PCR for rs11225395 (MMP8) consisted of $26 \mathrm{cy}$ cles and denaturation was performed at a temperature of $94^{\circ} \mathrm{C}$, alignment at $63.1^{\circ} \mathrm{C}$ and elongation at $72{ }^{\circ} \mathrm{C}$ for $30 \mathrm{~s}$. Similar PCR conditions were used for the rs2276109 (MMP12) variant, with the exception that alignment was carried out at $55^{\circ} \mathrm{C}$ for 40 cycles. The PCR products were subjected to digestion with the SfCl and HpyCH4ll enzymes for rs11225395 (MMP8) and rs2276109 (MMP12), respectively. Four units of the enzyme and $10 \mu \mathrm{L}$ of the PCR product were used. The fragments observed for rs11225395 (MMP8) corresponded to $399 \mathrm{bp}$ for the wild allele $(C)$ and $336 \mathrm{bp}$ and $62 \mathrm{bp}$ for polymorphic allele T. For rs2276109 (MMP12), the observed fragments were $163 \mathrm{bp}$ and $22 \mathrm{bp}$ for the wild allele (A) and $101 \mathrm{bp}, 62 \mathrm{bp}$, and $22 \mathrm{bp}$ for the polymorphic allele (G). As genotyping quality control, this procedure was randomly repeated in $20 \%$ of the samples. For digestion positive control, restriction enzymes were used with bacteriophage 
vector Lambda. The fragments were visualized on $6 \%$ polyacrylamide gels stained with silver nitrate.

\section{Statistical analysis}

Allelic and genotypic frequencies were estimated by direct count. Hardy-Weinberg equilibrium (HWE) was determined using the chi-square test. To measure the association between the variants and CRC, odds ratios (OR) and a $95 \%$ confidence interval $(\mathrm{Cl})$ were calculated. Arlequin v3.5 $5^{12}$ software was used to perform the haplotype analysis, and linkage disequilibrium (LD) was measured using the $r^{2}$ and $D^{\prime}$ coefficients. $r^{2}$ values $>0.33$ indicated a strong $L D$, and $D^{\prime}=1$ indicated complete LD. . $^{13,14}$ For all statistical analyses, a $p$-value $<0.05$ was regarded as significant.

\section{Results}

The characteristics of the 104 patients with CRC are shown in table 1. In these patients, tumor location was mainly in the colon (55\%). The reference group was characterized by individuals older than 18 years, out of whom $58 \%$ were males. The distribution of alleles and genotypes for variants rs11225395 (MMP8) and rs2276109 (MMP12) was in HWE ( $p>0.05)$, and no significant association was found. Single nucleotide variant (SNV) analysis, including the genetic models, is shown in table 2. The frequencies for rs 11568818 (MMP7) and rs2252070 (MMP13) were described in previous works. ${ }^{10}$

LD analysis was carried out considering the genotype frequency results reported by Moreno-Ortiz et al. (2014) for rs11568818 (MMP7) and rs2252070 (MMP13). Genotype frequencies of rs11225395 (MMP8) and rs2276109 (MMP12) variants showed imbalance for rs2276109 (MMP12) and rs2252070 (MMP13), with $D^{\prime}=1$ for the reference group and $D^{\prime}=0.74$ for the patients, and are reported in table 3 .

Haplotype inference for all SNVs led to the identification of 11 haplotypes for the reference group and 12 for the group of patients with CRC. However, only those with a frequency higher than $10 \%$ at each one of the groups are presented in table 4. Haplotypes rs11568818 (A)-rs11225395(T)-rs2276109(A)-rs2252070(A) and rs11568818(A) - rs11225395(C) - rs2276109(A) rs2252070 (G) showed an increase in the risk for CRC, and haplotypes rs11568818(G)-rs11225395(C)rs2276109(A)-rs2252070(A) and rs11568818(A)rs11225395(T)-rs2276109(A)-rs2252070(G) were associated with protection against CRC.
Table 1. Characteristics of the patients with colorectal cancer (CRC)

\begin{tabular}{|c|c|}
\hline Characteristics & Patients with CRC ( $\mathrm{n}=104)$ \\
\hline Age (years) & $59 \pm 14$ \\
\hline Weight (kg) & $68 \pm 15$ \\
\hline Height (m) & $1.7 \pm 10$ \\
\hline $\begin{array}{l}\text { Gender } \\
\text { Males } \\
\text { Females }\end{array}$ & $\begin{array}{l}53 \% \\
47 \%\end{array}$ \\
\hline $\begin{array}{l}\text { Presence of DM2 } \\
\text { Yes } \\
\text { No } \\
\text { NA }\end{array}$ & $\begin{array}{l}80 \% \\
16 \% \\
4 \%\end{array}$ \\
\hline $\begin{array}{l}\text { Overweight and/or obesity } \\
\text { Yes } \\
\text { No } \\
\text { NA }\end{array}$ & $\begin{array}{l}24 \% \\
52 \% \\
24 \%\end{array}$ \\
\hline $\begin{array}{l}\text { Alcohol consumption } \\
\text { Yes } \\
\text { No } \\
\text { NA }\end{array}$ & $\begin{array}{c}58 \% \\
34 \% \\
8 \%\end{array}$ \\
\hline $\begin{array}{l}\text { Tobacco consumption } \\
\text { Yes } \\
\text { No } \\
\text { NA }\end{array}$ & $\begin{array}{c}57 \% \\
39 \% \\
4 \%\end{array}$ \\
\hline $\begin{array}{l}\text { Physical activity } \\
\text { Yes } \\
\text { No } \\
\text { NA }\end{array}$ & $\begin{array}{l}54 \% \\
34 \% \\
12 \%\end{array}$ \\
\hline
\end{tabular}

DM2: type 2 diabetes mellitus; NA: data not available.

\section{Discussion}

In different types of cancer, MMP expression and activation are an important mark in tumor progression, including angiogenesis, invasion and metastasis. MMP elevated levels are also related to survival. ${ }^{5}$ Specific variants in MMP genes and their haplotypes could have an impact on their protein. In the present study, variants rs2276109 (MMP12) and rs2252070 (MMP13) showed imbalance, with this being mainly due to the distance between them because of their position in the chromosome. While variant rs2276109 (MMP12) is located at chr11:102875061, variant rs2252070 (MMP13) is located at chr11:102955810; i.e., there is a distance of 80,749 bp between them. In the chromosome, these are the genes that are closest to each other in comparison with the other analyzed MMPs. LD analysis was independently carried out for controls and CRC patients in order to 
Table 2. Comparison of variants rs11225395 and rs2276109 genotypical frequencies between colorectal cancer (CRC) patients and the reference group (healthy)

\begin{tabular}{|c|c|c|c|c|c|}
\hline \multirow[t]{2}{*}{ Gene/variant } & \multirow[t]{2}{*}{ Genotype/allele } & $\begin{array}{l}\text { Reference group (healthy) } \\
\text { n (\%) }\end{array}$ & $\begin{array}{c}\text { Patients with CRC } \\
n(\%)\end{array}$ & \multirow[t]{2}{*}{$\mathbf{p}^{*}$} & \multirow[t]{2}{*}{ OR } \\
\hline & & $n=112$ & $n=102$ & & \\
\hline \multirow[t]{8}{*}{ MMP8/rs11225395 } & $\mathrm{CC}$ & $40(36)$ & $32(31)$ & & 1.0 (reference) \\
\hline & $\mathrm{CT}$ & $53(47)$ & $53(52)$ & 0.46 & $1.25(0.68-2.27)$ \\
\hline & $\mathrm{TT}$ & $19(17)$ & $17(17)$ & 0.78 & $1.11(0.50-2-49)$ \\
\hline & C & $133(59)$ & $117(57)$ & & 1.0 (reference) \\
\hline & $\mathrm{T}$ & $91(41)$ & $87(43)$ & 0.67 & $1.08(0.73-1.59)$ \\
\hline & $\mathrm{CT}+\mathrm{TT}$ & $93(83)$ & $85(83)$ & & 1 (reference) \\
\hline & $\mathrm{CC}$ & $19(17)$ & $17(17)$ & 0.95 & $0.97(0.47-2.00)$ \\
\hline & & $n=102$ & $n=104$ & & \\
\hline \multirow[t]{7}{*}{ MMP12/rs2276109 } & AA & $89(87)$ & $89(86)$ & & 1.0 (reference) \\
\hline & $A G$ & $11(11)$ & $14(13)$ & 0.57 & $1.27(0.54-2.95)$ \\
\hline & $G G$ & $2(2)$ & $1(1)$ & 0.57 & $0.50(0.04-5.61)$ \\
\hline & A & $189(93)$ & $192(92)$ & & 1.0 (reference) \\
\hline & G & $15(7)$ & $16(8)$ & 0.89 & $1.05(0.50-2.18)$ \\
\hline & $A G+G G$ & $100(98)$ & $103(99)$ & & 1 (reference) \\
\hline & AA & $2(2)$ & $1(1)$ & 0.55 & $0.48(0.04-5.43)$ \\
\hline
\end{tabular}

determine the risk conferred by these genetic markers. The combination of these SNVs were in perfect LD $\left(D^{\prime}=1\right)$, demonstrating their strong association.

There have been no studies that have analyzed haplotypes with the variants presented in this study. The main haplotypes identified as a risk factor for CRC were MMP7 rs11568818(A)-MMP8 rs11225395(T)MMP12 rs2276109(A)-MMP13 rs2252070(A) (OR: 5.6; $95 \% \mathrm{Cl}: 2.4-12.8 ; p=0.001$ ) and MMP7 rs11568818(A)MMP8 rs11225395(C)-MMP12 rs2276109(A)-MMP13 rs2252070(G) (OR: 3.1; 95\% Cl: 1.2-7.9; $p=0.001$ ). In these haplotypes, the alleles that make them up have been associated with increased or decreased risk and even protection against different types of cancer such as CRC, ${ }^{10,15}$ liver cancer, ${ }^{15,16}$ breast cancer, lung cancer, hepatocellular carcinoma, esophageal adenocarcinoma and gastric cancer. ${ }^{15}$ Specifically, genotypes AA and AG, which are homozygous and heterozygous for MMP7 (rs11568818), respectively, were associated with risk for $\mathrm{CRC}$. Conversely, individuals with MMP13 (rs2252070) AA genotypes had three times higher risk for developing CRC. ${ }^{10}$ For the variant located in
Table 3. Linkage disequilibrium between analyzed variables

\begin{tabular}{|c|c|c|c|c|}
\hline Gene/variant & \multicolumn{2}{|c|}{$\begin{array}{c}\text { Reference group } \\
\text { (healthy) }\end{array}$} & \multicolumn{2}{|c|}{$\begin{array}{c}\text { Patients with } \\
\text { CRC }\end{array}$} \\
\cline { 2 - 5 } & D' & $r^{2}$ & D' & $r^{2}$ \\
\hline MMP7/rs11568818 & & & & \\
\hline MMP8/rs11225395 & 0.21 & 0.01 & 0.29 & 0.05 \\
\hline MMP12/rs2276109 & $\mathbf{0 . 8 2}$ & 0.07 & 0.32 & 0.02 \\
\hline MMP13/rs2252070 & 0.35 & 0.07 & 0.59 & 0.23 \\
\hline MMP8/rs11225395 & & & & \\
\hline MMP12/rs2276109 & $\mathbf{0 . 7 4}$ & 0.02 & $\mathbf{0 . 8 4}$ & 0.34 \\
\hline MMP13/rs2252070 & 0.51 & 0.10 & 0.27 & 0.03 \\
\hline MMP12/rs2276109 & & & & \\
\hline MMP13/rs2252070 & $\mathbf{1 . 0 0}$ & 0.20 & $\mathbf{0 . 7 4}$ & 0.15 \\
\hline
\end{tabular}

CRC: colorectal cancer.

MMP13, it is found in a consensus sequence for transcription factor PEA3, where the presence of allele A doubly increases the promoter activity. ${ }^{17}$ This variant is associated with a highly aggressive risk of oral cancer, and allele A appears to be a prognostic factor for tumor progression. ${ }^{18}$ Regarding MMP12 (rs2276109), 
Table 4. Haplotype frequencies and their association with CRC

\begin{tabular}{|c|c|c|c|c|c|c|c|c|}
\hline$\#$ & $\begin{array}{c}\text { MMP7/ } \\
\text { rs11568818 }\end{array}$ & $\begin{array}{c}\text { MMP8/ } \\
\text { rs11225395 }\end{array}$ & $\begin{array}{l}\text { MMP12/ } \\
\text { rs2276109 }\end{array}$ & $\begin{array}{l}\text { MMP13/ } \\
\text { rs2252070 }\end{array}$ & $\begin{array}{l}\text { Reference group } \\
\text { (healthy) }\end{array}$ & Patients with CRC & OR $(95 \% \mathrm{Cl})$ & p \\
\hline 1 & A & C & A & A & 0.46 & 0.72 & 1.0 (reference) & \\
\hline 2 & A & $\mathrm{T}$ & $A$ & A & 0.44 & 0.39 & $5.6(2.4-12.8)$ & $p=0.00$ \\
\hline 3 & G & C & A & A & 0.36 & 0.10 & $0.2(0.1-0.4)$ & $p=0.00$ \\
\hline 4 & A & C & A & G & 0.19 & 0.11 & $3.1(1.2-7.9)$ & $p=0.01$ \\
\hline 5 & A & T & A & G & 0.18 & 0.90 & $0.3(0.1-0.8)$ & $p=0.01$ \\
\hline 6 & G & T & A & G & 0.14 & 0.18 & $1.7(0.6-5.2)$ & $p=0.30$ \\
\hline 7 & G & $\mathrm{T}$ & A & $A$ & 0.09 & 0.19 & $0.6(0.1-2.9)$ & $p=0.50$ \\
\hline
\end{tabular}

CRC: colorectal cancer; OR: odds ratio; Cl: confidence interval.

allele $A$ has been found to be associated with high promoter activity, ${ }^{8,15}$ given that this variant is located at the binding site for transcription factor AP1, with higher affinity being demonstrated. ${ }^{8,19}$ For the MMP8 variant (rs11225395), allele T was associated with an increased risk of liver cancer in an American population. ${ }^{16}$

Haplotypes MMP7 rs11568818(G)-MMP8 rs11225395(C)-MMP12 rs2276109(A)-MMP13 rs2252070(A) (OR: 0.2; $95 \% \mathrm{Cl}: 0.1-0.4 ; \mathrm{p}=0.01$ ) and MMP7 rs11568818(A)-MMP8 rs11225395(T)-MMP12 rs2276109(A)-MMP13 rs2252070(G) (OR: 0.3; $95 \%$ $\mathrm{Cl}: 0.1-0.8 ; p=0.01$ ) appear to be protective factors against CRC. Some of the alleles that make up these haplotypes, in addition to being associated with risk, have also been identified for having protective effects against CRC. Variant rs11225395 (MMP8) allele T has been associated with low susceptibility for developing metastasis and also has indicated a better survival prognosis in patients with breast cancer. Similarly, in oral cancer, several reports have shown a low susceptibility to oral cancer. ${ }^{20}$ In addition, no significant relationships have been identified in children with leukemia in the Taiwanese population. ${ }^{21}$

In this sense, there has been no predominance of any specific allele. However, it should be noted that, in the rs11225395 (MMP8) variant, allele T has been associated with protection in different types of cancer. ${ }^{20,21}$ In this study, the comparison of rs 11225395 (MMP8) between the reference group and the group of patients with CRC did not show significant differences ( $p>0.05)$. However, this report represents the first study on the association of the r\$11225395 variant with $\mathrm{CRC}$ in a Mexican population. Regarding rs2276109 (MMP12), it is important to mention that allele $\mathrm{G}$ has the lowest frequencies in comparison with the other analyzed variants (MAF $=0.051000 \mathrm{Ge}$ nome Project), and that the absence of allele G could possibly play a role in the reduction of $\mathrm{CRC}$ risk.

It is important mentioning that, in haplotype MMP7 rs11568818(A)-MMP8 rs11225395(T)-MMP12 rs2276109(A)-MMP13 rs2252070(A), compared to another that was analyzed: MMP7-181A-MMP11607dupG-MMP3-1171A-82A, allele A predominated for the variants in MMP7 and MMP12. Furthermore, the analyzed haplotype was more frequent in patients with CRC than in healthy controls. ${ }^{8}$ Thus, it could be that there is a stronger haplotypic force deriving from the presence of a specific allele and not from the sum of all alleles. On the other hand, in the haplotype analysis of three SNVs (MMP8 rs2509013 C>T/MMP8 rs11225395 G>A/MMP27 rs3809017 T>C), ${ }^{22}$ most haplotypes that had $T$ were associated with a decrease in the recurrence of pregnancies; therefore, the influence of a single allele could be relevant.

\section{Conclusion}

Our results suggest that haplotypes rs11568818(A)rs11225395(T)-rs2276109(A)-rs2252070(A) and rs11568818(A)-rs11225395(C)-rs2276109(A)rs2252070(G) confer an increase in the risk for CRC, while haplotypes rs11568818(G)-rs11225395(C)rs2276109(A)-rs2252070(A) and rs11568818(A)rs11225395 (T)-rs2276109 (A)-rs2252070(G) act as a protective factor against CRC. LD was present between rs2276109 (MMP12) and rs2252070 (MMP13). Furthermore, it would be important for further studies to be carried out in order to show the possible impact a single allele might have as part of a haplotype. On 
the other hand, SNVs rs11225395 (MMP8) and rs2276109 (MMP12) did not show significant association with CRC. Regarding rs11225395 (MMP8), this is the first report in patients with CRC.

\section{Acknowledgements}

Ruth Ramírez-Ramírez, Anahí González-Mercado, Miriam Partida-Pérez, Alexis Sayuri Suárez-Villanueva and José Miguel Moreno-Ortiz thank for having received a CONACyT grant during Human Genetics Doctorate.

\section{Funding}

The authors received funding from Universidad de Guadalajara PROSNI program.

\section{Conflict of interests}

The authors declare that they have no conflicts of interest.

\section{Ethical responsibilities}

Protection of human and animal subjects. The authors declare that the procedures that were followed are in agreement with the regulations of the relevant clinical research ethics committee and with those of the Code of Ethics of the World Medical Association (Declaration of Helsinki).

Confidentiality of data. The authors declare that they have followed the protocols of their work center on the publication of patient data.

Right to privacy and informed consent. The authors have obtained written informed consent from the patients or subjects mentioned in the article. This document is in the possession of the corresponding author.

\section{References}

1. Douaiher J, Ravipati A, Grams B, Chowdhury S, Alatise O, Are C. Colorectal cancer-global burden, trends, and geographical variations. J Surg Oncol. 2017;115:619-30.
2. Bray F, Ferlay J, Soerjomataram I, Siegel RL, Torre LA, Jemal A. Global cancer statistics 2018: GLOBOCAN estimates of incidence and mortality worldwide for 36 cancers in 185 countries. CA Cancer J Clin. 2018;683:94-424.

3. Mathonnet M, Perraud A, Christou N, Akil H, Melin C, Battu S, et al. Hallmarks in colorectal cancer: angiogenesis and cancer stem-like cells. World J Gastroenterol. 2014;20:4189-96.

4. Cui N, Hu M, Khalil RA. Biochemical and biological attributes of matrix metalloproteinases. Prog Mol Biol Transl Sci. 2017;147:1-73.

5. Falk $P$, Jonsson A, Swartling $T$, Asplund D, Ivarsson ML. Role of matrix metalloproteinases in tumour invasion: immunohistochemistry of peritoneum from peritoneal carcinomatosis. Med Oncol. 2018;35:64.

6. Woo M, Park K, Nam J, Kim JC. Clinical implications of matrix metalloproteinase-1, -3, -7, -9, -12, and plasminogen activator inhibitor-1 gene polymorphisms in colorectal cancer. J Gastroenterol Hepatol. 2007;22:1064-70.

7. Yueh T, Wu CN, Hung YW, Chang WS, Fu CK, Pei JS, et al. The contribution of MMP-7 genotypes to colorectal cancer susceptibility in Taiwan. Cancer Genomics Proteomics. 2018:15:207-12.

8. Van Nguyen S, Skarstedt M, Löfgren S, Zar N, Anderson RE, Lindh M, et al. Gene polymorphism of matrix metalloproteinase-12 and -13 and association with colorectal cancer in Swedish patients. Anticancer Res. 2013;33:3247-50

9. Gustincich S, Manfioletti G, Del Sal G, Schneider C, Carninci P. A fast method for high-quality genomic DNA extraction from whole human blood. Biotechniques. 1991;11:298-302.

10. Moreno-Ortiz JM, Gutiérrez-Angulo M, Partida-Pérez M, Peregrina-Sandoval J, Ramírez-Ramírez R, Muñiz-Mendoza R, et al. Association of MMP7-181A/G and MMP13-77A/G polymorphisms with colorectal cancer in a Mexican population. Genet Mol Res. 2014;13:3537-44

11. Li Y, Jia JH, Kang S, Zhang XJ, Zhao J, Wang N, et al. The functional polymorphisms on promoter region of matrix metalloproteinase-12, -13 genes may alter the risk of epithelial ovarian carcinoma in Chinese. Int J Gynecol Cancer. 2009;19:129-33.

12. Excoffier L, Lischer HEL. Arlequin suite ver 3.5: Anew series of programs to perform population genetics analyses under Linux and Windows. Mol Ecol Resour. 2010;10:564-7.

13. Lewentin RC. The interaction of selection and linkage. I. General consideration; heterotic model. Genetics. 1964;49:49-67.

14. Ardlie KG, Kruglyak L, Seielstad M. Patterns of linkage disequilibrium in the human genome. Nat Rev Genet. 2002;3:299-309.

15. Chen SS, Song J, Tu XY, Zhao JH, Ye XQ. The association between MMP12-82A/G polymorphism and susceptibility to various malignant tumors: a meta-analysis. Int J Clin Exp Med. 2015;8:10845-54.

16. Kader AK, Shao L, Dinney CP, Schabath MB, Wang Y, Liu J, et al. Matrix metalloproteinase polymorphisms and bladder cancer risk. Cancer Res. 2006;66:11644-8.

17. Yoon S, Kuivaniemi H, Gatalica Z, Olson JM, Butticè G, Ye S, et al. MMP13 promoter polymorphism is associated with atherosclerosis in the abdominal aorta of young black males. Matrix Biol. 2002;21:487-98.

18. Vairaktaris E, Yapijakis C, Nkenke E, Serefoglou ZC, Chatzitheofylaktou A, Vassiliou S, et al. A metalloproteinase-13 polymorphism affecting its gene expression is associated with advanced stages of oral cancer. Anticancer Res. 2007;27:4027-30.

19. Jormsjo S, Ye S, Moritz J, Walter DH, Dimmeler S, Zeiher AM, et al. Allele-specific regulation of matrix metalloproteinase-12 gene activity is associated with coronary artery luminal dimensions in diabetic patients with manifest coronary artery disease. Circ Res. 2000;86:998-1003.

20. Hung YW, Tsai CW, Wu CN, Shih LC, Chen YY, Liu YF, et al. The contribution of matrix metalloproteinase-8 promoter polymorphism to oral cancer susceptibility. In Vivo. 2017;31:585-90.

21. Pei JS, Chang WS, Hsu PC, Hung YW, Cheng SP, Tsai CW, et al. The contribution of MMP-8 promoter genotypes to childhood leukemia. In Vivo. 2017;31:1059-64.

22. Park HS, Ko KH, Kim JO, An HJ, Kim YR, Kim JH, et al. Association study between the polymorphisms of matrix metalloproteinase (MMP) genes and idiopathic recurrent pregnancy loss. Genes (Basel). 2019;10:347. 